\title{
HEK293 cell culture media study: increasing cell density for different bioprocess applications
}

\author{
Leticia Liste-Calleja*, Martí Lecina, Jordi Joan Cairó \\ From 23rd European Society for Animal Cell Technology (ESACT) Meeting: Better Cells for Better Health \\ Lille, France. 23-26 June 2013
}

\begin{abstract}
Background
The increasing demand for biopharmaceuticals produced in mammalian cells has lead industries to enhance bioprocess volumetric productivity through different strategies. Among them, media development is of major interest [1]. According to the increasing constraints regarding the use of animal derived components on industrial bioprocesses but also the drawbacks of its depletion from cell culture [2], the main goal of the present work was to provide different cell culture platforms which are suitable for a wide range of applications depending on the type and the final use of the product obtained.
\end{abstract}

\section{Materials and methods}

The cell line HEK293SF-3F6 employed in this study was kindly provided by Dr. A.Kamen, NRC-BRI. The basal media tested were CDM4HEK293, SFM4HEK293 and SFMTransFx-293 (Hyclone, Thermo Scientific) supplemented -when indicated- with FBS (Invitrogen) and/or Cell Boost 5 ( $80 \mathrm{~g} / \mathrm{L})$ (Hyclone, Thermo Scientific). Viable cell density and viability were determined by trypan blue exclusion method and manual counting using an haemocytometer. The adenovirus strain HAdV-5 $(\triangle \mathrm{E} 1 / \mathrm{E} 3)$ encoding $\mathrm{pCMV}-\mathrm{GFP}$ was used for infection experiments. All infections were carried out at $\mathrm{MOI} \approx 1$ TOI $\approx 0.5 \times 10^{6} \mathrm{cell} / \mathrm{mL}$ in 6 -well-plate. Harvesting was performed $48 \mathrm{hpi}$.

Viral titration was performed by Flow cytometry on a FACS Canto (Becton and Dickinson, Bioscience) by adaption of a protocol previously described [3].

\section{Results}

The first part of this work was focused on screening different serum-free cell culture media specifically recommended

\footnotetext{
* Correspondence: Leticia.Liste@uab.cat

Chemical Engineering Department, Universitat Autònoma de Barcelona,
} Cerdanyola del Vallès, 08193, Spain for HEK293 cell line. As shown in Figure 1A top panel, cultures performed in HyQ SFM4HEK293 and HyQ SFMTransFx-293 showed better cell growth than HyQ CDM4HEK293, reaching maximum cell densities of about $3.5 \times 10^{6} \mathrm{cell} / \mathrm{mL}, 2 \times 10^{6} \mathrm{cell} / \mathrm{mL}$ and less than $1 \times 10^{6}$ cell $/ \mathrm{mL}$ respectively. In order to evaluate whether the substitution of critical serum components have satisfactorily been performed in the media tested without affecting cell growth, the addition of fetal bovine serum (FBS) was assessed. FBS depletion was acceptable only in $\mathrm{HyQ}$ SFM4HEK293 as the other cell media reached higher cell densities when FBS was added (up to 7-fold increment of $\left.\mathrm{Xv}_{\text {max }}\right)$. Regarding the screening of Animal derived component free supplements, three chemically defined supplements were tested but only one (Cell Boost 5 , onwards CB5) significantly enhanced cell growth. This supplement enabled to reach higher cell densities in all media tested: 2-fold up in HyQ SFM4HEK293 and CDM4HEK293 and 5-fold increment in HyQ SFMTransFx-293 (Figure 1A, bottom panel).

The results obtained so far showed that supplementation of all cell media tested is recommended in order to achieve higher cell density cultures. Among all the conditions, HyQSFMTransFx-293 was the media which supported the highest $\mathrm{Xv}_{\max }$ with both supplements (FBS and CB5). Therefore, this medium was selected for tuning the final concentration of each supplement. Among the studied concentration range for FBS $(2.5-10 \% \mathrm{v} / \mathrm{v})$ and for CB5 (2.5-20\%) it was determined that the best conditions were $5 \%$ for FBS and $10 \%$ for CB5 solution. At these concentrations, $\mathrm{Xv}_{\max }$ achieved were $\left(7.14 \pm 0.56 * 10^{6} \mathrm{cell} / \mathrm{mL}\right)$ and $\left(12.63 \pm 1.76^{*} 10^{6} \mathrm{cell} / \mathrm{mL}\right)$ respectively (Figure $1 \mathrm{~B}$ ). Interestingly, CB5 enabled to extend $\mu_{\max }$ phase while FBS increased $\mu_{\max }$ value, as previously detected in the initial media screening (Table 1). The combination of supplements (5\% FBS and $10 \% \mathrm{CB} 5)$ resulted in an $\mathrm{Xv}_{\max }$ as high as $16.77 \pm 0.70 \times 10^{6} \mathrm{cell} / \mathrm{mL}$ in batch culture, with an 


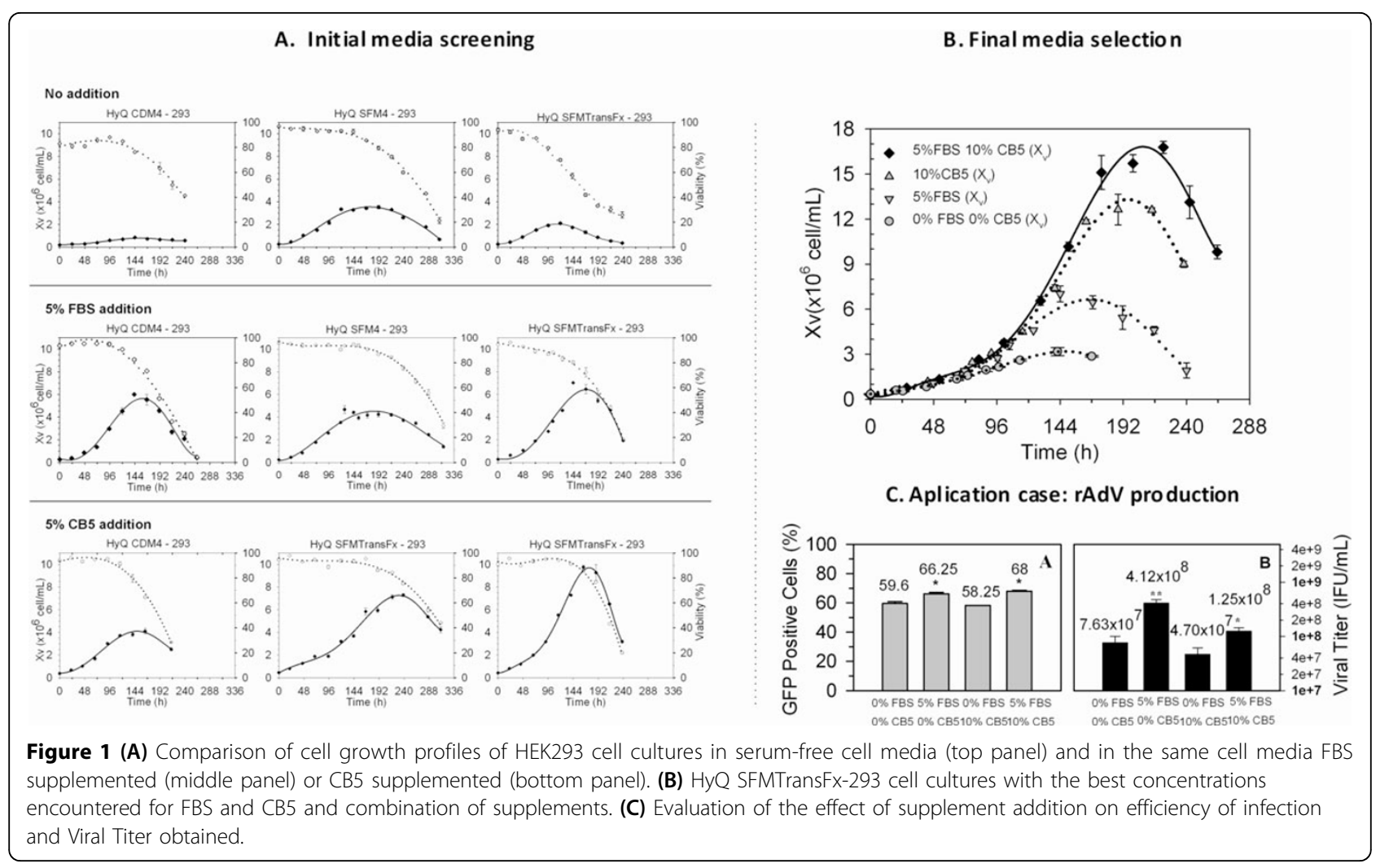

increment in specific growth rate of $15 \%$ in comparison to those cultures in which FBS was deprived. Specific growth rate was maintained for $144 \mathrm{~h}$ of cell culture.

From the range of applications in which HEK293 can be used, the work carried out in this work was directed to recombinant adenovirus production. Hence, the evaluation of the effect of supplementation in the cell media selected on adenovirus infection efficiency and final titer obtained was evaluated (Figure 1C). Efficiency of infection was around $63 \%$ as expected for an effective infection [4] in all conditions. In regards to adenovirus production, FBS increased it up to fivefold, whereas CB5 supplementation did not affect significantly, and the addition of both supplements almost doubled the viral production in comparison to basal medium. It is proposed that an increment of osmolarity due to the addition of both supplements might explain the slight reduction on productivity in comparison to the addition of FBS solely [5].

\section{Conclusions}

Two culture platforms are proposed for two possible scenarios in basis of the $\mathrm{Xv}_{\max }$ reached: (1) HyQSFMTransFx-293 CB5 supplemented $-10 \% \mathrm{v} / \mathrm{v}$ - for animal derived component Free required bioprocesses $\left(\mathrm{Xv}_{\max }=\right.$ $12.6 \times 10^{6} \mathrm{cell} / \mathrm{mL}$ ) and (2) HyQSFMTransFx-293 FBS

Table 1 Kinetic parameters for HEK293 cell cultures corresponding to the profiles depicted in Figure 1.

\begin{tabular}{lllll}
\hline & & HyQ CDM4HEK293 & HyQ SFM4HEK293 & $\begin{array}{l}\text { HyQ } \\
\text { SFMTransFx-293 }\end{array}$ \\
\hline No adition & $X v_{\max }\left(\times 10^{6} \mathrm{cell} \cdot \mathrm{mL}^{-1}\right)$ & $0.85 \pm 0.0$ & $3.53 \pm 0.21$ & $2.1 \pm 0.12$ \\
& $\mu_{\max }\left(\times 10^{-2} \mathrm{~h}^{-1}\right)$ & $1.06 \pm 0.01$ & $2.46 \pm 0.14$ & $2.43 \pm 0.03$ \\
& $\mathrm{t}_{\mu}(\mathrm{h})$ & 96 & 74 & 74 \\
\hline $5 \%$ FBS & $X v_{\max }\left(\times 10^{6} \mathrm{cell} \cdot \mathrm{mL}^{-1}\right)$ & $6 \pm 0.0$ & $4.67 \pm 0.48$ & $7.02 \pm 0.06$ \\
& $\mu_{\max }\left(\mathrm{h}^{-1}\right)$ & $2.61 \pm 0.04$ & $2.8 \pm 0.05$ & $2.67 \pm 0.01$ \\
& $\mathrm{t}_{\mu}(\mathrm{h})$ & 95 & 71 & 72 \\
\hline $5 \%$ CB5 & $\mathrm{X}_{\max }\left(\times 10^{6} \mathrm{cell} \cdot \mathrm{mL}^{-1}\right)$ & $4.11 \pm 0.33$ & $7.29 \pm 0.18$ & $9.75 \pm 0.25$ \\
& $\mu_{\max }\left(\mathrm{h}^{-1}\right)$ & $2.1 \pm 0.06$ & $2.06 \pm 0.03$ & $2.17 \pm 0.03$ \\
& $\mathrm{t}_{\mu}(\mathrm{h})$ & 92 & 69 & 116 \\
\hline
\end{tabular}


and CB5 supplemented $-5 \%$ and $10 \% \mathrm{v} / \mathrm{v}$ respectivelyfor animal derived component containing bioprocesses $\left(\mathrm{Xv}_{\max }=16.7 \times 10^{6} \mathrm{cell} / \mathrm{mL}\right)$. In both cases, $\mu_{\max }$ and $t_{\mu}$ values were preserved or even improved with respect to basal media and any of the supplements negatively affected the adenovirus production when compared to non-supplemented infections.

\section{Acknowledgements}

We would like to thank Dr. Amine Kamen (BRI-NRC, Canada) for kindly providing the HEK 293 cell line.

Published: 4 December 2013

\section{References}

1. Burgener A, Butler M: Medium Development. In Cell Culture Technology For Pharmaceutical And Cell-Based Therapies. 1 edition. Boca Ratón, FL: CRC Press;Ozturk S, Hu WS 2006:41-80.

2. Keenan J, Pearson D, Clypes M: The role of recombinant proteins in the development of serum-free media. Cytotechnology 2006, 50:49-56.

3. Gálvez J, Lecina M, Solà C, Cairó JJ, Gòdia F: Optimization of HEK-293S cell cultures for the production of adenoviral vectors in bioreactors using on-line OUR measurements. J Biotech 2012, 157:214-222.

4. Condit RC: Principles of Virology. In Fields Virology.. 5 edition. Lippencott: Williams and Wilkins;Knipe DM, Howley PM 2007:25-58.

5. Dormond $E$, Perrier $M$, Kamen A: From the first to the third generation adenoviral vector: what parameters are governing the production yield? Biotechnology advances 2009, 27:133-144.

doi:10.1186/1753-6561-7-S6-P51

Cite this article as: Liste-Calleja et al:: HEK293 cell culture media study: increasing cell density for different bioprocess applications. BMC Proceedings 2013 7(Suppl 6):P51.

\section{Submit your next manuscript to BioMed Central} and take full advantage of:

- Convenient online submission

- Thorough peer review

- No space constraints or color figure charges

- Immediate publication on acceptance

- Inclusion in PubMed, CAS, Scopus and Google Scholar

- Research which is freely available for redistribution

Submit your manuscript at www.biomedcentral.com/submit
C Biomed Central 